\title{
MENINGKATKAN KETERAMPILAN MENYIMAK DALAM PEMBELAJARAN BAHASA ARAB SISWA DENGAN METODE AURAL ORAL APPROACH
}

\author{
AZIZ AKHMAD NAJIB \\ MTs Negeri 2 Purwakarta \\ e-mail: azizahmadnajib@gmail.com
}

\begin{abstract}
ABSTRAK
Penelitian ini dilaksanakan di Kelas VIII C MTsN 2 Purwakarta. Penelitian ini bertujuan untuk mendeskripsikan proses peningkatan keterampilan menyimak dalam pembelajaran bahasa Arab pada siswa kelas VIII C MTsN 2 Purwakarta dengan menggunakan metode Aural Oral Approach, mulai dari proses perencanaan, pelaksanaan dan evaluasi. Selain itu, penelitian ini menggunakan pendekatan deskriptif kualitatif dan tindakan kelas. Untuk mengetahui peningkatan keterampilan menyimak siswa dengan menggunakan metode AOA, penelitian ini dilakukan dalam dua siklus, dan setiap siklus menggunakan dua kali pertemuan. Penelitian ini diawali dengan pre-test dan diakhiri dengan post-test. Hasil penelitian menunjukkan bahwa dengan menggunakan metode AOA/Audio-lingual, skor perbandingan untuk pre-test dan posttest meningkat secara signifikan. Hal ini terlihat dari perbandingan nilai perbandingan siswa yang memiliki KKM khusus vokal mengalami peningkatan 51,94\%, konsonan 42,59\%, intonasi 43,98\%, pantun dan kata-kata penekanan 37,40\%, dan kefasihan 42,59\%.
\end{abstract}

Kata Kunci: Bahasa Arab, Aural Oral Approach, Menyimak.

\section{PENDAHULUAN}

Bahasa Arab merupakan mata pelajaran yang mengembangkan keterampilan berkomunikasi lisan dan tulisan untuk memahami dan mengungkapkan informasi, pikiran, perasaan serta mengembangkan ilmu pengetahuan, teknologi, dan budaya. Sesuai dengan fungsinya sebagai alat untuk menyampaikan dan menyerap gagasan-gagasan, pikiran, pendapat dan perasaan baik secara lisan maupun tertulis, maka kurikulum ini dipersiapkan untuk pencapaian keterampilan dasar awal berbahasa Arab peserta didik, dengan didukung oleh unsur-unsur/aspek-aspek kebahasaan seperti: menyimak (إستماع), berbicara (كلام), membaca (قراءة), dan menulis (كتابة)

Standar Kompetensi Pengajaran bahasa Arab adalah berkomunikasi lisan dan tertulis dengan menggunakan bahasa Arab serta pola kalimat yang tepat sesuai konteks dalam wacana interaksional atau monolog yang informative, naratif, dan deskriptif. Area pelajaran utama dari pembelajaran bahasa Arab meliputi empat aspek yaitu menyimak, berbicara, membaca, dan menulis. Keempat aspek tersebut saling berhubungan. Misalnya, keterampilan mendengarkan memberikan konstribusi terhadap perkembangan keterampilan berbicara, dan sebaliknya yang pada gilirannya kedua keterampilan tersebut akan diperkuat oleh keterampilan membaca peserta didik atau sebalikya. Keterampilan menulis memberikan konstribusi pada keterampilan membaca dalam bentuk teks atau dokumentasi dan keterampilan mendengar, berbicara dan membaca sangat berpengaruh pada keterampilan menulis.

Dalam pembelajaran Bahasa Arab di Madrsah Tsanawiyah keterampilan menyimak merupakan keterampilan awal yang harus dikuasai siswa, karena dengan keterampilan ini siswa dapat melafalkan atau berbicara bahasa Arab dengan baik. Untuk pencapain amanat kurikulum di atas, di dalam pengajaran Bahasa Arab terutama dalam keterampilan menyimak (استماع), ternyata di lapangan banyak kendala-kendala yang peneliti temukan. Di antara kendala tersebut adalah Problem kebahasaan yang sering disebut problem linguistik dan Problem non kebahasaan atau problem non linguistik.

Pengetahuan guru tentang kedua problem itu penting, agar guru dapat meminimalisasi problem tersebut dan dapat mencari solusi yang tepat untuk mengatasinya. Sehingga apa yang diharapkan dari pengajaran bahasa Arab dalam batas-batas minimal dapat tercapai dengan baik. 
Problem kebahasaan antara lain meliputi problem aswat arabiyah, problem qowa'id dan i'rab, dan problem tarokib.

Adapun problem non kebahasaan antara lain meliputi Motivasi dan minat belajar, Sarana belajar, Kompetensi guru baik akademik maupun paedagogik, kepribadian dan sosial, Metode pembelajaran yang digunakan, dan waktu yang tersedia. Dari kedua problem di atas nampaknya yang paling dominan mempengaruhi berhasil tidaknya pembelajaran bahasa Arab adalah problem-problem non kebahasaan yang salah satunya adalah metode.

Berpijak dari uraian di atas maka penelitian ini tentang: "Meningkatkan keterampilan menyimak dalam pembelajaran bahasa arab dengan metode Aural Oral Approach di MTs Negeri 2 Purwakarta ini dilakukan. Permasalahan dalam penelitian ini dirumuskan sebagai berikut: (1) Bagaimana efektivitas penggunaan metode Aural Oral Approach dapat meningkatkan keterampilan menyimak dalam pembelajaran bahasa Arab di MTs Negeri 2 Purwakarta? (3) Seberapa besar peningkatan keterampilan menyimak dalam pembelajaran bahasa Arab di MTs Negeri 2 Purwakarta dengan menggunakan metode Aural Oral Approach?

Adapun tujuan penelitian ini adalah: (1) mengetahui efektivitas penggunaan metode Aural Oral Approach dapat meningkatkan keterampilan menyimak dalam pembelajaran bahasa Arab di MTs Negeri 2 Purwakarta; (1) mengetahui hasil peningkatan keterampilan menyimak dalam pembelajaran bahasa Arab di MTs Negeri 2 Purwakarta dengan menggunakan metode Aural Oral Approach.

\section{METODE PENELITIAN}

Penelitian ini dilaksanakan di kelas VIII C di MTs Negeri 2 Purwakarta yang berlokasi di Jl. Warungkandang Plered-Purwakarta. Terkait dengan penelitian ini yang akan dijadikan sebagai sumber data adalah siswa-siswi Kelas VIII C di MTs Negeri 2 Purwakarta. Dilihat dari permasalahannya penelitian ini termasuk deskriptif kualitatif. Penelitian kualitatif merupakan studi lapangan, Peneliti mengumpulkan data dalam rentang waktu yang cukup lama dalam suatu lingkungan tertentu dari sejumlah individu. Kesimpulan-kesimpulan dalam penelitian ini harus ditarik dalam konteks keterpaduan dalam setting tersebut.

Sedangkan penelitian deskriptif (descriptive research) yaitu suatu bentuk penelitian yang paling dasar ditujukan untuk mendeskripsikan atau menggambarkan fenomena-fenomena yang ada, baik yang bersifat alamiah ataupun rekayasa manusia. Penelitian ini mengkaji bentuk, aktifitas, karakteristik, perubahan, hubungan, kesamaan dan perbedaaannya dengan fenomena lain. Penelitian deskriptif tidak memberikan perlakuan, manipulasi atau pengubahan pada variabel-variabel bebas, tetapi menggambarkan sesuatu apa adanya.

Dengan demikian yang dimaksud dengan penelitian deskriptif kualitatif adalah penelitian dengan cara memaparkan dan menguraikan secara detail hasil data penelitian yang berasal dari lapangan. Peneliti menggunakan rancangan deskriptif kualitatif karena dengan rancangan tersebut, maka penelitian yang dilakukan dilapangan akan lebih mudah dipaparkan.

Adapun jenis penelitian ini adalah penelitian tindakan kelas. Penelitian ini dilakukan secara kolaboratif dan partisipatif, kolaboratif dalam arti dilakukan dengan kerjasama antara peneliti dengan guru mata pelajaran sejawat. Sedangkan secara partisipatif tim ini (guru dan peneliti) akan bekerjasama mulai tahap orientasi dilanjutkan dengan menyusun perencanaan

Dalam penelitian ini, peneliti bertindak sebagai penyaji pembelajaran, sehingga mitra peneliti (guru dan pengamat lain) yang akan bertindak sebagai observer perlu mendapatkan pemahaman (choaching) terlebih dahulu untuk membuat catatan lapangan dengan lengkap dan terutama tentang aspek-aspek pembelajaran yang perlu mendapat perhatian karena menjadi focus permasalahan yang diteliti.

Adapun rancangan (desain) PTK yang dipergunakan dalam penelitian ini adalah model spiral dari Kemmis dan Mc. Taggart (1988). Alur (langkah) pelaksanaan tindakan dimaksud dapat dilihat pada gambar di bawah . 


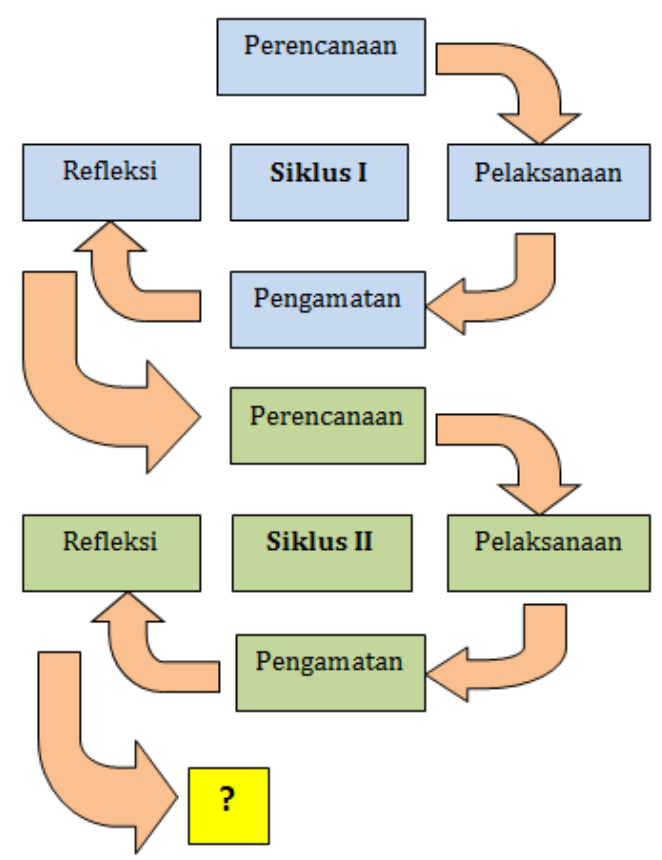

\section{Gambar 1. Siklus Pembelajaran}

Peneliti pada tahap pertama menyusun rencana skenario tentang apa yang telah dilakukan, dan perilaku apa yang diharapkan terjadi pada siswa sebagai reaksi atas tindakan yang akan dilakukan, dalam hal ini penggunaan metode AOA (Aural Oral Approach)/Audio lingual dapat meningkatkan keterampilan menyimak dalam pembelajaran bahasa Arab. Di dalam skenario tesebut disebutkan pula fasilitas yang diperlukan, sarana pendukung proses pembelajaran, alat, serta cara merekam perilaku selama proses berlangsung.

Pada tahap kedua, peneliti melaksanakan rencana tindakan sesuai skenario. Terkait dengan tindakan kelas yang dilakukan oleh peneliti, maka rencana tindakan meliputi: perencanaan satuan pelajaran dan strategi pembelajaran, tes pengecekan keterampilan awal siswa, panduan evaluasi, panduan instrument penelitian, dan pedoman observasi.

Pelaksanaan tindakan meliputi pelaksanaan rencana yang telah disiapkan. Adapun tindakan yang dilakukan adalah dengan teknik Aural Oral Approach /Audio - Lingual. Tahap ketiga pada alur daur tersebut adalah monitoring atau pemantauan. Pada tahap monitoring, tindakan yang dilakukan adalah mengobsevasi proses pembelajaran dengan menggunakan check list observasi. Adapun hal yang diobservasi adalah peningkatan menyimak siswa. Observasi dilakukan oleh peneliti sendiri dengan menggunakan membuat catatan (field note) yang didasarkan pada pedoman observasi.

Tahap keempat adalah refleksi. Dengan refleksi ini peneliti dapat melakukan evaluasi terhadap apa yang telah dilakukannya. Hasil observasi dianalisis dan dipergunakan untuk evaluasi terhadap prosedur, proses, serta hasil tindakan. Jika ternyata belum memuaskan, maka perlu ada perancangan ulang untuk diperbaiki, dimodifikasi, dan jika perlu, disusun skenario baru jika sama sekali tidak memuaskan.

\section{HASIL DAN PEMBAHASAN}

\section{Hasil}

Menggunakan metode Aural Oral Approach terbukti dapat meningkatkan keterampilan menyimak (إستماع) siswa kelas VIII C di MTs Negeri 2 Purwakarta, dengan indikator keberhasilan sebagai berikut: (1) Selama pembelajaran berlangsung siswa tampak senang dan antusias. Walaupun pada pertemuan pertama kurang antusias, seiring dengan berjalnnya tidakan pada pertemuan selanjutnya dapat diatasi. (2) Hasil (nilai) yang diperoleh siswa lebih 
baik atau meningkat dari hasil yang diperoleh sebelumnya. (3) Siswa menjadi lebih aktif berlatih untuk mendaptkan nilai yang lebih baik.

Sejarah Metode Aural Oral Approach atau Metode Audio - lingual pertama kali dicetuskan oleh Fries, seorang profesor dari Universitas Michigan Amerika. Metode ini bersandar pada teori-teori dari linguistik struktural. Pengertian metode Aural Oral Approach adalah metode yang didasarkan pada pandangan teori linguistik struktural dan pandangan linguistik behavior. Menurut Brook, ada empat tujuan pembelajaran bahasa asing, yaitu: (1) Menyimak: melalui latihan menyimak, pembelajar dapat menangkap gambaran dari bunyi bahasa. (2) Berbicara: berdasarkan auditory image yang telah didapat, pembelajar dapat mengucapkan bunyi bahasa dengan tepat. (3) Membaca: bunyi bahasa yang diucapkan diverifikasi dengan huruf, kemudian pembelajar dapat mengucapkan bunyi bahasa dari huruf yang tercetak tersebut. Dengan kata lain pembelajar telah dapat membaca. (4) Menulis: bunyi bahasa yang telah diverifikasi dengan lambang tersebut kemudian ditulis kembali dengan kaidah-kaidah yang sesuai.dengan demikian pembelajar telah mampu menulis. Dengan demikian, metode Aural Oral Approach dilakukan dengan tahapan mendengar, berbicara, membaca, dan menulis. Tetapi metode pengajaran yang berfokus pada membaca dan menulis akan sangat berbeda dengan metode Aural Oral Approach.

Pada dasarnya pembelajaran difokuskan pada kegiatan percakapan dan drill. Melalui kegiatan percakapan pembelajar dikenalkan dengan penggunaan bahasa secara nyata oleh native speaker, kemudian untuk membiasakan pembelajar pada model tersebut difokuskan pada latihan mimicry - memorization.

Selajutnya, dari kalimat percakapan tersebut dipilih pola kalimat yang penting untuk dijadikan pattren practice seperti drill, mengganti kata, melengkapi kalimat, expand, merubah bentuk, kombinasi, dan lain-lain. Latihan yang ditekankan pada level pelafalan adalah latihan minimal pair. Latihan ini merupakan latihan pelafalan yang didasarkan pada pandangan teori strukturalis sehingga berbasis pada morfem. Penjelasan tata bahasa pada metode AOA (Aural Oral Approach)/audio - lingual ini tergantung pada analogi induksi atau merujuk pada hal-hal sebelum atau sesudah pembelajaran mandiri. Adakalanya materi yang akan diberikan, sudah diajarkan pada pertemuan sebelumnya.

\section{Pembahasan \\ Siklus ke - 1 pertemuan ke - 1 dilaksanakan pada tanggal 2 Mei 2011.}

Hasil evaluasi keterampilan menyimak (إستماع) siswa pada siklus ke - 1 pertemuan ke 1 dilihat dari segi diskriminasi bunyi pada vokal adalah; 7 orang siswa $(18,42 \%)$ memperoleh nilai 40,16 orang siswa $(42,11 \%)$ memperoleh nilai 45,1 orang siswa $(2,63 \%)$ memperoleh nilai 60,12 orang siswa $(31,58 \%)$ memperoleh nilai 65,2 orang siswa $(5,26 \%)$ memperoleh nilai 70 . Adapun nilai rata-rata kelas dari diskriminasi bunyi pada vokal adalah $52,11 \%$. Hasil evaluasi keteampilan menyimak (إستماع)siswa dilihat dari diskriminasi bunyi pada konsonan adalah; 1 orang siswa $(2,63 \%)$ memperoleh nilai 40,4 orang siswa $(10,53 \%)$ memperoleh nilai 45,18 orang siswa $(47,37 \%)$ memperoleh nilai 50,11 orang siswa $(28,95 \%)$ memperoleh nilai 65 , dan 4 orang siswa $(10,37 \%)$ memperoleh nilai 70 . Sedangkan nilai rata-rata kelas dari segi diskriminasi bunyi pada konsonan adalah 55,66.

Hasil penilaian menyimak (إستماع)dilihat dari segi intonasi diperoleh rata-rata kelas 55,26 dengan rincian sebagaiberikut: 3 orang siswa (7,89\%) memperoleh nilai 40, 6 orang siswa $(15,79 \%)$ memperoleh nilai 45,13 orang siswa $(34,21 \%)$ memperoleh nilai 50,12 orang siswa $(31,58 \%)$ memperoleh nilai 65 , dan 4 orang siswa $(10,37 \%)$ memperoleh nilai 70 .

Dalam penilaian menyimak (إستماع) dilihat dari segi ritme dan penekanan kata diperoleh rata-rata kelas 56,58 dengan rincian perolehan nilai siswa sebagai berikut; 3 orang siswa $(7,89 \%)$ memperoleh nilai 40,5 orang siswa $(13,16 \%)$ memperoleh nilai 45,12 orang siswa $(31,58 \%)$ memperoleh nilai 50, 11 orang siswa $(28,95 \%)$ memperoleh nilai 65 , dan 7 orang siswa $(18,42)$ memperoleh nilai 70 . 
Sedangkan penilaian menyimak (إستماع) dilihat dari segi kelancaran diperoleh nilai ratarata kelas 55,13, dengan rincian penilaian sebagai berikut; 2 oarang siswa $(5,26 \%)$ memperoleh nilai 40,8 orang siswa $(21,05 \%)$ memperoleh nilai 45,10 orang siswa $(26,32)$ memperoleh nilai 50,5 orang siswa $(13,16 \%)$ memperoleh nilai 55,6 orang siswa $(15,79 \%)$ memperoleh nilai 65 , 7 orang siswa $(18,42 \%)$ memperoleh nilai 70 .

Pada pertemuan ke -2 siklus ke -1 ini, terlihat siswa lebih antusias mengikuti pembelajaran. Selain peneliti mengubah pendekatan cara mengajar yang digunakan, peneliti juga memberikan reward pada siswa yang mendapat nilai yang terbaik.

\section{Siklus ke - 1 pertemuan ke - 2 dilaksanakan pada tanggal 9 Mei 2011.}

Hasil evaluasi keterampilan menyimak (إستماع) siswa pada pertemuan ke - 2 ini setelah melakukan pen-drillan pada siswa mengalami peningkatan. Berikut ini rincian nilai keterampilan menyimak (إستماع) siswa pada pertemuan ke -2 siklus ke - 1. Dilihat dari segi diskriminasi bunyi pada vokal diperoleh nilai rata-rata kelas $57,87,22$ orang siswa $(57,89 \%)$ memperoleh nilai 50,1 orang siswa $(2,63 \%)$ memperoleh nilai 60,1 orang siswa $(2,63 \%)$ memperoleh nilai 65,1 orang siswa $(2,63 \%)$ memperoleh nilai 66,2 orang siswa $(5,26 \%)$ memperoleh nilai 67,9 orang siswa $(23,68 \%)$ memperoleh nilai 70 , dan 2 orang siswa $(5,26 \%)$ memperoleh nilai 72 . Berdasarkan data tersebut di atas dapat disimpulkan nilai rata-rata kelas menyimak (إستماع)dilihat dari segi diskriminasi bunyi pada vokal pada pertemuan ke -2 siklus ke -1 ini mengalami peningkatan dibandingkan dengan pertemuan ke -1 siklus ke -1 , yaitu $11,06 \%$.

Sedangkan hasil penilaian menyimak (إستماع)siswa dilihat dari segi diskriminasi bunyi pada konsonan pada pertemuan ke - 2 siklus ke - 1 diperoleh nilai rata-rata kelas 59,45, dengan rincian hasil nilai siswa siswa sebagai berikut; 1 orang siswa $(2,63 \%)$ memperoleh nilai 40,4 orang siswa $(10,53 \%)$ memperoleh nilai 45,18 orang siswa $(47,37 \%)$ memperoleh nilai 50, 11 orang siswa $(28,95 \%)$ memperoleh nilai 65 , dan 4 orang siswa $(10,53 \%)$ memperoleh nilai 70.

Berdasarkan dari data antara pertemuan ke -1 siklus ke 1 dan pertemuan ke -2 siklus ke - 1 dapat disimpulkan penilaian menyimak (إستماع) siswa dilihat dari segi diskriminasi bunyi pada konsonan mengalami peningkatan yaitu $6,81 \%$.

Hasil penilaian menyimak (إستماع) siswa dilihat dari segi intonasi pada pertemuan ke -2 siklus ke - 1 untuk rata-rata kelas 58,79, dengan rincian hasil yang diperoleh masing-masing siswa sebagai berikut; 19 orang siswa $(50,00 \%)$ memperoleh nilai 50,3 orang siswa $(7,89 \%)$ mendapatkan nilai 60,2 orang siswa $(5,26 \%)$ mendapatkan nilai 65,1 orang siswa $(2,63 \%)$ mendapatkan nilai 66,2 orang siswa $(5,26 \%)$ mendapatkan nilai 67,9 orang siswa $(23,68 \%)$ mendapatkan nilai 70 , dan 2 orang siswa $(5,26 \%)$ mendapatkan nilai 72 .

Dari data di atas dapat disimpulkan bahwa penilaian menyimak (استماع) siswa dilihat dari segi intonasi mengalami peningkatan, yaitu $6,38 \%$

Dalam penilaian menyimak (إستماع)siswa dilihat dari segi ritme dan penekanan kata pada pertemuan ke -2 siklus ke -1 perolehan nilai siswa sebagai berikut; 3 orang siswa $(7,89 \%)$ memperoleh nilai 45,14 orang siswa $(36,84 \%)$ memperoleh nilai 50,3 orang siswa $(7,89 \%)$ memperoleh nilai 60,4 oarang siswa $(10,53 \%)$ memperoleh nilai 65,1 orang siswa $(2,63 \%)$ memperoleh nilai 66,2 orang siswa $(5,26 \%)$ memperoleh nilai 67,9 orang siswa $(23,68 \%)$ memperoleh nilai 70, dan 2 orang siswa $(5,26 \%)$ memperoleh nilai 72 . Adapun nilai rata-rata kelas pada segi ritme dan penekanan kata adalah 59,18.

Dalam penilaian ini dapat disimpulkan bahwa menyimak (إستماع)siswa dilihat dari segi ritme dan penekanan kata mengalami peningkatan, yaitu $4,60 \%$.

Sedangkan penilaian menyimak (إستماع)dilihat dari segi kelancaran nilai yang diperoleh siswa pada peretemuan ke -2 siklus ke -1 adalah sebagai berikut; 6 oarang siswa $(15,79 \%)$ memperoleh nilai 45,16 orang siswa $(42,11 \%)$ memperoleh nilai 50,1 orang siswa $(2,63 \%)$ memperoleh nilai 60,2 orang siswa $(5,26 \%)$ memperoleh nilai 65,1 orang siswa $(2,63 \%)$ memperoleh nilai 66,1 orang siswa $(2,63 \%)$ memperoleh nilai 67,9 orang siswa $(23,68 \%)$ 
memperoleh nilai 70,2 orang siswa $(5,26 \%)$ memperoleh nilai 72 . Adapun nilai rata-rata kelas 57,03 .

Dari data di atas dapat disimpulkan bahwa penilaian menyimak (إسنماع)siswa dilihat dari segi kelancaran mengalami peningkatan, yaitu 3,44\%. Adapaun data penabulasian penilaian menyimak (إستماع)siswa pada siklus ke - 1 dapat dilihat pada lampiran-lampiran. Jadi setelah dilakukan tindakan pada pertemuan ke -2 , siswa mengalami peningkatan dalam keterampilan menyimak (استماع).

\section{Siklus ke - 2 pertemuan ke - 1 dilaksanakan pada tanggal 16 Mei 2011.}

Dari hasil observasi pula peneliti dapat menyimpulkan bahwa keterampilan menyimak ( (استماع) siswa sudah mengalami banyak peningkatan. Kesalahan-kesalahan pelafalan sudah tidak banyak terjadi. Dan tentunya nilai yang diperoleh siswa juga banyak mengalami peningkatan.

Hasil penilaian keterampilan menyimak (إستماع)siswa pada pertemuan ke - 1 siklus ke - 2 ini, dalam segi diskriminasi bunyi pada vokal adalah; 3 orang siswa $(7,89 \%)$ memperoleh nilai 55,1 orang siswa $(2,63 \%)$ memperoleh nilai 60,22 orang siswa $(57,89 \%)$ memperoleh nilai 65,1 orang siswa $(2,63 \%)$ memperoleh nilai 70,9 orang siswa $(23,68 \%)$ memeperoleh nilai 75,2 orang siswa $(5,26 \%)$ memperoleh nilai 76 . Adapun nilai rata-rata kelas pada penilaian keterampilan menyimak (إستماع)siswa dilihat dari segi diskriminasi bunyi pada vokal adalah 67,16. Meningkat dari rata-rata awal sebelum ada tindakan sebesar 52,11. Porsentase peningkatan ini, yaitu sebesar $28,89 \%$.

Sedangkan penilaian siswa dilihat dari segi diskriminasi bunya pada konsonan pada pertemuan ke - 1 siklus ke -2 ini, untuk rata-rata kelas 68,68 , dengan rincian nilai siswa sebagai berikut: 1 orang siswa $(2,63 \%)$ memperoleh nilai 60,20 orang siswa $(52,63 \%)$ memperoleh nilai 65,5 orang siswa $(13,16 \%)$ memperoleh nilai 70,1 orang siswa $(2,63 \%)$ memperoleh nilai 71,9 orang siswa $(23,68 \%)$ memperoleh nilai 75 , dan 2 oarng siswa $(5,26 \%)$ memeperoleh nilai 77. Adapun prosentase peningkatannya yaitu $23,40 \%$.

Dari segi intonasi diperoleh rata-rata kelas 67,16 , dengan rincian 2 orang siswa $(5,26 \%)$ memperoleh nilai 55, 4 orang siswa $(10,53 \%)$ memperoleh nilai 60,19 orang siswa $(50,00 \%)$ memperoleh nilai 65,2 orang siswa $(5,26 \%)$ memperoleh nilai 70,9 orang siswa $(23,68 \%)$ memperoleh nilai 75 , dan 2 orang siswa $(5,26 \%)$ memperoleh nilai 76 . Adapun porsentase peningkatan sebesar $21,52 \%$.

Pada penilaian ritma dan penekanan kata rata-rata kelas 67,68 dengan rincian; 1 orang siswa $(2,63 \%)$ memperoleh nilai 55,1 orang siswa $(2,63 \%)$ memperoleh nilai 60,24 orang siswa $(63,16 \%)$ memperoleh nilai 65,1 orang siswa $(2,63 \%)$ memperoleh nilai 70,9 orang siswa $(23,68 \%)$ memperoleh nilai 75 , dan 2 orang siswa $(5,26 \%)$ memperoleh nilai 76.

Adapun hasil evaluasi dari segi kelancaran pada pertemuan ke -1 siklus ke -2 ini ratarata kelas 68,21 dengan rincian, 1 orang siswa $(2,63 \%)$ memperoleh nilai 60,23 orang siswa $(60,53 \%)$ memperoleh nilai 65,3 orang siswa $(7,89 \%)$ memperoleh nilai 70,9 orang siswa $(23,68 \%)$ memperoleh nilai 75 , dan orang siswa $(5,26 \%)$ memperoleh nilai 76 . Prosentase peningkatan sebesar $34,42 \%$.

Pada pertemuan ke -2 siklus ke -2 , sebagaimana telah dijelaskan di atas peneliti melaksanakan post test.pada post test tersebut siswa-siswa mengalami peningkatan yang cukup besar. Jumlah siswa yang melakukan kesalahan pelafalan semakin sedikit.

Adapun hasil keterampilan menyimak (إستماع) siswa pada pertemuan ke - 2 siklus ke 2 ini setelah dilakukan pen-drillan pada 2 pertemuan sebelumnya adalah sebagai berikut; dilihat dari segi diskriminasi bunyi pada vokal diperoleh data; 31 orang siswa $(81,58 \%)$ memperoleh nilai 70 , dan 7 orang siswa $(18,42 \%)$ memperoleh nilai 80 . Adapun rata-rata kelas yang diperoleh 71,84. Prosentase peningkatannya dapat diketahui sebesar 51,94\%. Dilihat dari konsonan diperoleh data; 31 orang siswa $(81,58 \%)$ memperoleh nilai 70 dan 7 orang siswa $(18,42 \%)$ memperoleh nilai 80 . Adapun rata-rata kelas yang diperoleh 71,84. Prrosentase peningkatanya sebesar $42,59 \%$. 
Hasil evaluasi pertemuan ke -2 siklus ke -2 dari segi intonasi diperoleh rata-rata kelas 71,97. Adapun rinciannya; 5 orang siswa $(13,16 \%)$ memperoleh nilai 65,23 orang siswa $(60,53 \%)$ memperoleh nilai 70 , dan 10 orang siswa (26,32\%) memperoleh nilai 80 . Prosentase peningkatan sebesar $43,98 \%$.

Dari segi ritma dan penekanan kata dapat diperoleh rata-rata kelas 70,79. Rincian nilai sebagai berikut; 8 orang siswa $(21,05 \%)$ memperoleh nilai 65,23 orang siswa $(60,53 \%)$ memperoleh nilai 70 , dan 7 orang siswa $(18,42 \%)$ memperoleh nilai 80 . Adapun prosentase kenaikannya sebesar $37,40 \%$. Adapun penilaian dari segi kelancaran rata-rata kelas dapat diperoleh 71,32, dengan rincian nilai sebagai berikut; 4 orang siswa $(10,53 \%), 27$ orang siswa $(71,05 \%)$ memperoleh nilai 70 , dan 7 orang siswa $(18,42 \%)$ memperoleh nilai 80 . Prosentase peningkatannya sebesar $42,59 \%$.

Dari hasil penelitian ini, peneliti menarik kesimpulan bahwa keterampilan menyimak siswa setelah diberikan tindakan pada pertemuan ke - 2 siklus ke - 2 mengalami peningkatan yang pesat. Penelitian ini dilakukan sebanyak dua siklus, yang bertujuan untuk mengetahui apakah penggunaan metode Aural Oral Approach dapat meningkatkan keterampilan menyimak (إستماع) siswa kelas VIII C Terkait dengan penelitian ini yang akan dijadikan sebagai sumber data adalah siswa-siswi Kelas VIII C di MTs Negeri 2 Purwakarta.

Adapun variabel yang diamati pada tindakan kelas tersebut adalah metode Aural Oral Approach dan peningkatan keterampilan menyimak (استماع). Adapun indikator peningkatan keterampilan menyimak (إستماع) siswa ditunjukkan dengan peningkatan nilai siswa pada setiap siklus.

Sementara sumber belajar yang digunakan dalam penelitian ini adalah buku paket bahasa Arab kelas VIII karangan Maman Abdul Djaliel yang juga didukung dengan buku-buku lain, kamus Arab Indonesia, lembar dialog (حوار), dan kurikulum dan standar kompetensi mata pelajaran bahasa Arab.

Setelah melihat hasil evaluasi pada pertemuan ke - 1, peneliti mulai menerapkan metode Aural Oral Approach pada pertemuan ke - 2. Peneliti mulai men-drill siswa dengan metode AOA (Aural Oral Approach)/Audio - Lingual. Siswa mulai menunjukkan semangat mempelajari dialog (حوار)dengan keterampilan menyimak إستماع))yang baik dan benar. Metode Aural Oral Approach yang digunakan sudah mulai tampak dapat diterima siswa. Meskipun masih ada beberapa siswa yang lamban menerimanya, namun secara umum penerapan metode ini suda h mulai tampak keberhasilanya.

Secara kuantitatif juga, bahwa keterampilan menyimak (إستماع) siswa pada saat pre test masih tergolong rendah. Hal itu dapat dilihat dari hasil pre test siswa. Banyak nilai pre test siswa yang berada di bawah kriteria ketuntasan minimal (KKM) yang ditetapkan sekolah untuk mata pelajaran bahasa Arab, yaitu 65.

Dari katagori diskriminasi bunyi yang dilihat dari segi vokal jumlah siswa yang memenuhi KKM hanya 14 orang siswa $(36,84 \%)$. Sedangkan sebanyak 24 orang siswa $(63,16 \%)$ masih belum memenuhi KKM. Adapun dari katagori bunyi yang dilihat dari segi konsonan jumlah siswa yang memenuhi KKM 15 orang siswa $(39,47 \%)$ dan sisanya 23 orang siswa $(60,53 \%)$ belum memenuhi KKM.

Hasil evaluasi dari segi initonasi terdapat 16 orang siswa $(42,11 \%)$ yang memenuhi KKM, sedangkan sisanya 22 orang siswa $(57,89 \%)$ belum memenuhi KKM. Dari segi ritma dan penekanan kata yang memenuhi KKM sebanyak 18 orang siswa (47,37\%) sedangkat sisanya 20 orang siswa $(52,63 \%)$ belum memenuhi KKM yang ditetapkan.

Sedangkan hasil evaluasi dari segi kelancaran siswa yang memenuhi KKM sebanyak 13 orang siswa $(34,21 \%)$ dan sisanya 25 orang siswa $(65,79 \%)$ belum memenuhi kriteria ketuntasan minimal (KKM). Dari rician nilai di atas dapat dilihat bahwa dari empat kriteria yang dinilai, yaitu diskriminasi bunyi (vokal dan konsonan), intonasi, ritma dan penekanan kata, dan dari segi kelancaran, siswa mendaptkan nilai terendah pada kriteria terakhir yaitu dari segi kelncara pelafalan. Karena pada kriteria ini jumlah siswa yang belum memenuhi KKM sebanyak 25 orang $(67,79 \%)$. 
Hasil evaluasi pada pertemuan ke -1 siklus ke -1 ini dijadikan acuan peneliti untuk pertemuan ke -2 siklus ke -1 . Pada pertemuan ke -2 siklus ke -1 ini peneliti mulai melakukan pen-drillan pada siswa, selain itu peneliti menstimuli siswa agar lebih bersemangat lagi dengan memberi reward pada pertemuan terakhir bagi siswa yang memperoleh nilai yang terbaik. Rupanya keduanya itu cukup ampuh untuk membangkitkan semangat siswa. Terlihat nilai yang diperoleh siswa mengalami peningkatan dibandingkan dengan pertemuan ke -1 . Dari segi diskriminasi bunyi pada vokal pada pertemuan ke -1 jumlah siswa yang memenuhi KKM sebanyak 14 orang $(36,84 \%)$, pada pertemuan ke -2 ini sebanyak 15 orang siswa $(39,47 \%)$. Ada peningkatan walau pun baru 1 orang siswa $(2,63 \%)$. Sedangkan pada konsonan pada pertemuan ke - 1 yang memenuhi KKM sebanyak 15 orang siswa $(39,47 \%)$. Pada pertemuan ke -2 pun masih sama yaitu sebanyak 15 orang siswa (39,47\%), belum terlihat peningkatannya.

Pada penilaian dari segi intonasi pada pertemuan ke -1 , jumlah siswa yang memenuhi KKM sebanyak 16 orang siswa (42,11\%), begitu juga pada pertemuan ke -2 , masih sama yaitu 16 orang siswa $(42,11 \%)$, belum ada peningkatan. Hasil penilaian siswa yang memenuhi KKM dari segi ritma dan penekanan kata pada pertemuan ke - 1 dan ke - 218 orang siswa (47,37\%), belum terlihat peningkatannya. Adapun hasil penilian siswa yang memenuhi KKM dilihat dari segi kelancaran pada pertemuan ke -1 adalah 13 orang siswa $(34,21 \%)$. Pada pertemuan ke 2 yang memenuhi KKM sebanyak 15 orang siswa $(39,47 \%)$, meningkat sebanyak 2 orang siswa $(5,26 \%)$. Setelah melihat hasil test siswa pada pertemuan-pertemuan sebelumnya, peneliti memutuskan untuk melaksanakan post test pada siswa. Post test tersebut dilaksanakan bukanlah tanpa pertimbangan, akan tetapi post test tersebut dilaksanakan setelah melihat keterampilan menyimak (إستماع)siswa meningkat (yang dindikasikan dengan meningkatnya hasil nilai siswa). Pada post test tersebut para siswa mengalami peningkatan yang cukup besar. Jumlah siswa yang melakukan kesalahan pelafalan juga semakin sedikit. Dalam post tes ini juga sudah tidak ada siswa yang nilainya di bawah KKM.

Dari segi diskriminasi bunyi pada vokal jumlah siswa yang memenuhi KMM pada post test ini sebanyak 38 orang siswa (100\%), yang berarti sudah tidak ada siswa yang masih memperoleh nilia di bawah KKM yang ditetapkan. Prosentase peningkatannya pada post test ini sebanyak $60,53 \%$ dari hasil pre test. Begitu pula pada konsonan semua siswa $(100 \%)$ memenuhi standar KKM yang telah ditentukan. Prosentase peningkatanya sama dengan penilaian pada vokal yaitu 60,53\%. Pada penilaian keterampilan menyimak (إستماع) siswa pada segi intonasi, jumlah siswa yang memenuhi KKM sebanyak 38 orang siswa (100\%), prosentase peningkatan dilihat dari pre test ke post test sebanyak 57, 89\%. Dari segi ritma dan penekanan kata jumlah siswa yang memenuhi KKM 38 orang siswa (100\%), prosentase peningkatnnya sebanyak 52,63\% dari pre test. Begitu pun dari segi kelancaran jumlah siswa yang memenuhi KKM sebanyak 38 orang siswa (100\%), prosentase peningkatannya sebanyak $60,53 \%$ dari hasil pre tes.

Dengan demikian, dari data-data hasil penelitian yang telah dipaparkan di atas terbukti bahwa dengan menggunakan metode Aural Oral Approach dapat meningkatkan keterampilan menyimak (إستماع) siswa kelas VIII C di MTs Negeri 2 Purwakarta, dengan indikator keberhasilan sebagai berikut: (1) Selama pembelajaran berlangsung siswa tampak senang dan antusias. Walaupun pada pertemuan pertama kurang antusias, seiring dengan berjalnnya tidakan pada pertemuan selanjutnya dapat diatasi. (2) Hasil (nilai) yang diperoleh siswa lebih baik atau meningkat dari hasil yang diperoleh sebelumnya. (3) Siswa menjadi lebih aktif berlatih untuk mendaptkan nilai yang lebih baik.

\section{KESIMPULAN}

Adapun peningkatan dari segi diskrimansi bunyi pada vokal terdapat peningkatan sebesar 51,94\%, dari segi diskrimansi bunyi pada konsonan terdapat peningkatan sebesar $42,59 \%$, pada intonasi terdapat peningkatan sebesar 43,98\%, pada ritma dan penekanan kata tersapat peningkatan sebesar $37,40 \%$, dan pada kelancaran terdapat peningkatan sebesar 42,59\%. Dengan begitu dapat disimpulkan bahwasanya penggunaan metode Aural Oral 
Approach dapat meningkatkan keterampilan menyimak (إستماع) siswa kelas VIII C di MTs Negeri 2 Purwakarta Indikator peningkatannya adalah; Selama pembelajaran berlangsung siswa tanpak senang dan antusias. Walaupun pada pertemuan pertama kurang antusias, seiring dengan berjalnnya tidakan pada pertemuan selanjutnya dapat diatasi, hasil (nilai) yang diperoleh siswa lebih baik atau meningkat dari hasil yang diperoleh sebelumnya, dan siswa menjadi lebih aktif berlatih untuk mendaptkan nilai yang lebih baik.

\section{DAFTAR PUSTAKA}

Abdul Djaliel, Maman. (2009). Bahasa Arab Madrasah Tsanawiyah Untuk Kelas VIII, Semester 1 dan 2. Bandung: Armico

Arikunto, Suharsimi. (1998). Prosedur Penelitian suatu Tindakan Praktek, Jakarta: Rhineka Cipta.

Arikunto, Suharsimi. (2002). Prosedur Penelitian (Suatu Pendekatan Praktek) Edisi Revisi V. Jakarta: Rhineka Cipta.

Arikunto, Suharsimi dkk. (2007). Penelitian Tindakan Kelas. Jakarta: Bumi Aksara.

B. Uno, Hamzah. (2007). Model Pembelajaran, Mencptakan Proses Belajar Mengajar yang Kreatif dan Efektif. Jakarta: Bumi Aksara

Daryono, dkk. (2008). Fasih Berbahasa Arab Untuk Kelas VIII MTs. Solo : PT. Tiga Serangkai Departemen Agama. (2007). Standar Kompetensi Lulusan (SKL), Standar Kompetensi (SK), dan Kompetensi Dasar (KD, serta Model Pengembangan Silabus Mata Pelajaran Bahasa Arab Madrasah Tsanawiyah, Jakarta: Direktorat Jenderal Kelembagaan Agama Islam

Depdikbud. (1989). Kamus Besar Bahasa Indonesia. Jakarta : Balai Pustaka.

Depdiknas. (2003). KBK, Kompetensi Bahasa Indonesia, SLTP/MTs. Jakarta : Depdiknas.

Dwiwandono, S. (1996). Tes Bahasa dan Pengajaran. Bandung: ITB Press

Halim, A. (1974). Ujian Bahasa. Jakarta : Ganaco N.V

Hanafiah, dkk. (LKS Al Amin) Bahasa Arab Untuk Madrasah Tsanawiyah Kelas VIII. Klaten: Sinar Mandiri

Hidayat, D. (2008). Pelajaran Bahasa Arab Kelas VIII. Semarang: Toha Putra

Littlewood, W. (1983). Communicative Language Teaching. New York: Cambridge University Press.

Mujib, Fathul, dkk. (2011). Metode Permainan-Permainan Edukatif dalam Belajar Bahasa Arab. Jogjakarta: Diva Press

Mujib, Fathul, dkk. (2011). Permainan Edukatif Pendukung Pembelajaran Bahasa Arab (2). Jogjakarta: Diva Press

Oller, J.W. (1979). Language Test At School. London: Logman Group.

Supriadi, Yudi. (2005). Bahasa Arab Madrasah Tsanawiyah Kurikulum Berbasis Kompetensi Jilid 2 Kelas II. Bandung: Titian Ilmu

Tarigan, Djago, dkk. (1990). Materi Pokok Pendidikan Bahasa Indonesi I. Jakarta: P2LPTK, depdikbud.

Tarigan, H.G. (1986). Menyimak Sebagai Keterampilan Berbahasa. Bandung: Penerbit Angkasa.

Wiraatmadja, Rochiati. (2007). Metode Penelitian Tindakan Kelas. Bandung: Rosdakarya 